\title{
First record of Tuxophorus caligodes (Siphonostomatoida, Tuxophoridae) in sea-farmed cobia, Rachycentron canadum, in Brazil
}

\author{
Primeiro relato de Tuxophorus caligodes (Siphonostomatoida, Tuxophoridae) \\ em cultivo de cobias, Rachycentron canadum, no Brasil
}

\begin{abstract}
Ana Carolina da Silva ${ }^{1}$; Julieta Rodini Engrácia de Moraes ${ }^{1 *}$; Antonio Mataresio Antonucci ${ }^{2}$; Marina Tie Shimada ${ }^{1}$; Ricardo Massato Takemoto ${ }^{2}$; Jair Rodini Engrácia Filho할 Flávio Ruas de Moraes ${ }^{1}$

\author{
${ }^{1}$ Departamento de Patologia Veterinária, Faculdade de Ciências Agrárias e Veterinárias, Universidade Estadual Paulista - UNESP, \\ Jaboticabal, SP, Brasil \\ ${ }^{2}$ Núcleo de Pesquisas em Limnologia Ictiologia e Aquicultura - NUPÈLIA, Laboratório de Ictioparasitologia, \\ Universidade Estadual de Maringá - UEM, Maringá, PR, Brasil
}

Received May 16, 2012

Accepted July 12, 2012

\begin{abstract}
The cobia is the only representative of the Rachycentridae family and, because of its zootechnical qualities, production of this fish has been implemented in several countries, such as the United States, Mexico and Brazil. Tuxophorus caligodes is a widespread parasite of marine fish worldwide. For the present report, 15 juvenile cobias were collected from net cages on a fish farm in Ilhabela, state of São Paulo, Brazil, in the winter of 2011. The fish were sacrificed by means of cerebral concussion, and then weighed $(280 \pm 70.5 \mathrm{~g})$ and measured $(27 \pm 1.97 \mathrm{~cm})$. After external examination under a stereomicroscope, ectoparasites present on the body surface were collected, fixed and processed for identification. Out of the 15 fish examined, two were parasitized with Tuxophorus caligodes, thus indicating a prevalence of $13.3 \%$. This is the first report of Tuxophorus caligodes in cobias in Brazil.
\end{abstract}

Keywords: Ectoparasite, copepod, Rachycentron canadum, Brazil.

\section{Resumo}

O cobia é o único representante da família Rachycentridae e, devido às suas qualidades zootécnicas, a produção desse peixe tem sido implementada em vários países, tais como os Estados Unidos, México e Brasil. Tuxophorus caligodes é um parasito de peixes marinhos amplamente distribuído no mundo. Para o presente relato, 15 juvenis de cobias foram coletados de tanques-rede, em uma fazenda marinha em Ilhabela, Estado de São Paulo, Brasil, no inverno de 2011. Os peixes foram sujeitos à eutanásia por meio de concussão cerebral, pesados $(280 \pm 70,5 \mathrm{~g})$ e medidos $(27 \pm 1,97 \mathrm{~cm})$. Após exame externo sob um estereomicroscópio, os ectoparasitos presentes na superfície do corpo foram coletados, fixados e processados para identificaçáo. Dos 15 peixes examinados, dois apresentavam-se parasitados indicando a prevalência de 13,3\%. Esse é o primeiro relato de Tuxophorus caligodes em cobias no Brasil.

Palavras-chave: Ectoparasito, copépode, Rachycentron canadum, Brasil.

The cobia or ling is the only representative of the Rachycentridae family. It is a neritic, epipelagic carnivorous fish of active habit because of its lack of a swim bladder. It has migratory behavior and widespread distribution in the tropical and subtropical zones of all the oceans. It inhabits the entire coast of Brazil and can be found in estuaries and bays. It reaches a weight of $68 \mathrm{~kg}$ and a length of up to $2 \mathrm{~m}$, with a life expectancy of 15 years (SHAFFER; NAKAMURA, 1989; FIGUEIREDO; MENEZES, 2000).

\footnotetext{
*Corresponding author: Julieta Rodini Engrácia de Moraes

Departamento de Patologia Veterinária, Faculdade de Ciências Agrárias e Veterinárias,

Universidade Estadual Paulista - UNESP, Jaboticabal, SP, Brasil

e-mail: julietaengracia@gmail.com
}

Extractive sea fishing is in decline, but increasing worldwide demand for fish has stimulated investment in aquaculture (VARELA, 2005), given that marine fish are among the best-quality and most abundant food resources (LUQUE, 2004).

Because of the zootechnical quality of cobia, production of this fish has been implemented in several countries, such as the United States, Mexico and Brazil (SCHWARZ et al., 2007).

Studies have demonstrated that few parasite species are considered to be a problem for fish health in marine environments (PAVANELLI et al., 2000), and for a long time, knowledge of such species consisted solely of species descriptions (LUQUE, 2004). 
Pavanelli et al. (2008) stated that these pathogens could act as disease promoters among farmed fish. These authors established a direct relationship between greater stocking density and increased prevalence and incidence of such parasites.

Parasitism has pathogenic action with responses that are stereotypical but difficult to quantify because of varying degrees of infestation and different organs affected (EIRAS, 2004). Low levels of infestation may cause reductions in growth and provide a gateway for other pathogenic agents (WOO, 2010).

Information on the impact of parasitoses on farmed cobia is scarce, but in Penghu County (Taiwan), parasitic infestation was reported to be surpassed only by bacterial diseases, with an infection rate of $28 \%$ (McLEAN et al., 2008).

Copepods are the ectoparasites that have perhaps the most wide-ranging forms of action on fish hosts, going from minimally pathogenic action by mobile parasites to situations of deep lesions in which these crustaceans acquire reduced motility. In fish presenting immunosuppression due to stress, parasitosis caused by copepods occurs on the body surface and leads to irritation and lesions that form the gateway for a variety of pathogens. This process may culminate in high mortality (VARELA, 2005).

Tuxophorus is a genus of caligid copepods with wide geographical distribution, occurring in the Pacific, Atlantic and Indian oceans (YAMAGUTI, 1963; CRESSEY et al., 1983). The genus Tuxophorus was proposed by Wilson (1908), and the type species, Tuxophorus caligodes, was collected from Rachycentron canadum and Echeneis naucrates in North Carolina, USA (CAUSEY, 1953). Tuxophorus caligodes was recorded in Brazil, on the coast of the state of Rio de Janeiro in Mugil platanis by Knoff et al. (1994); in Scomberomorus sp. by Luque et al. (1998); in Selene vomer by Cezar et al. (2000); in Oligoplites saliens, Oligoplites palometa and Oligoplites saurus by Takemoto and Luque (2002); and in Trachinotus goodei by Luque and Cezar (2004). Until now, observations relating to occurrences of this parasite and infection caused by it in sea-farmed $R$. canadum were unknown in Brazil.

For the present report, 15 juvenile cobia were collected from net tanks on a fish farm in the municipality of Ilhabela, state of São Paulo, Brazil, in the southern hemisphere winter of 2011.

The fish were sacrificed by means of cerebral concussion, their overall length was measured $(\mathrm{cm})$ and they were weighed $(\mathrm{g})$. Their mean weight was $280 \pm 70.5 \mathrm{~g}$ and their mean overall length was $27 \pm 1.97 \mathrm{~cm}$. After external examination under a stereomicroscope, the ectoparasites present on the body surface near the edge of the operculum were collected with the aid of tweezers, and were fixed and processed as described by Eiras et al. (2006). The specimens found were measured, as presented below, and the mean values are indicated between parentheses.

Out of the 15 fish examined, two were parasitized, thus indicating a prevalence of $13.3 \%$. A total of three specimens of T. caligodes were found, comprising one male and two females, with the following measurements: overall length, 3.00-5.00 mm (4.46); maximum width, $1.88-2.85 \mathrm{~mm}$ (2.21); cephalothorax length, 2.15-2.50 mm (2.38); and length of egg sacs, 0.50-2.00 mm (1.25).

These values are similar to those found in O. saliens and O. palometa by Takemoto and Luque (2002), in which the parasites had an overall length of 2.85-5.16 mm (4.38); maximum width, 1.79-2.52 mm (2.27); cephalothorax length, 1.73-2.37 mm
(2.18); and length of egg sacs, $2.47 \mathrm{~mm}(\mathrm{n}=1)$. Because of the low level of infestation, no relevant clinical signs were observed.

The interest in the present report comes from the local economic importance of the fish, its good performance and the epidemiological importance of this parasite in relation to sea-farms. The presence of parasitic copepods has been reported in cobia in other regions of the world, both in free-living and in sea-farmed specimens, but the impact of the disease has not been documented and no estimates of the economic losses due to these infestations have been made. The impact relates directly to disease severity, host size and age, host health status, parasite species and developmental stages present. Heavy infestations can result in host death due to osmotic imbalance or because entry points for other pathogens are provided. The economic losses incurred, other than direct mortality of farmed fish, are generally due to the reduced growth of infected fish, the negative impact on edible tissues, the presence of residues from chemical treatments and the costs of the treatments themselves (JOHNSON et al., 2004; McLEAN et al., 2008).

Infection of the gills of Borneo mullet (Liza macrolepis) with extremely high numbers of the ergasilid copepod Diergasilus kasaharai, was found to result in gill inflammation, necrosis, high levels of mucous production and death of the hosts (LIN; HO, 1998). In Chile, it has been recognized that infection with sea lice can predispose fish to the development of other diseases such as infectious pancreatic necrosis, bacterial kidney disease and salmonid rickettsial septicemia. These diseases are difficult to treat and can result in high levels of mortality (JOHNSON et al., 2004). Overstreet et al. (2009) showed that parasitic crustaceans (shrimps) are an additional potential means of transmitting and disseminating three disease-causing agents: Taura Syndrome Virus (TSV), White Spot Syndrome Virus (WSSV), and Yellowhead Virus (YHV).

The infestation of $R$. canadum by T. caligodes reported here is the first report of such parasitism in Brazil. This parasite may become a problem in aquaculture because of the possibility that this may cause production losses due to the ensuing depreciation of the flesh, reduced growth, costs of treatments and fish mortality, and because it may serve as a vector for other pathogenic agents.

\section{Acknowledgements}

This study formed part of a research project supported by Coordenaçấo de Aperfeiçoamento de Pessoal de Nível Superior (Capes), Edital Ciências do Mar 09/2009.

\section{References}

Causey D. Parasitic copeopoda of Texas coastal fishes. Pub Inst Mar Sci 1953; 3: 7-16.

Cezar AD, Luque Jl, Chaves ND. Estrutura das infracomunidades de metazoários ectoparasitos do peixe-galo, Selene vomer (Linnaeus, 1758) (Osteichthyes, Carangidae), do litoral do estado do Rio de Janeiro, Brasil. Contrib Avulsas Hist Nat Bras, Sér Zool 2000; 16: 1-7. 
Cressey RF, Collette BB, Russo JL. Copepods and scombrid fishes: A study in host-parasite relationships. Fish Bull 1983; 81(2): 227-65.

Eiras JC, Takemoto RM, Pavanelli GC. Métodos de estudos e técnicas laboratoriais em parasitologia de peixes. 2. ed. Maringá: Eduem; 2006.

Eiras JC. Aspectos Gerais da Patologia das Parasitoses de Peixes Marinhos. In: Ranzani-Paiva MJT, Takemoto RM, Lizama MLAP. Sanidade de Organismos Aquáticos. São Paulo: Editora Varela; 2004. p. 143-156.

Figueiredo JL, Menezes NA. Manual de peixes marinhos do sudeste do Brasil: VI. Teleostei. Sáo Paulo: Museu de Zoologia da Universidade de São Paulo; 2000

Johnson SC, Treasurer JW, Bravo S, Nagasawa K, Kabata Z. A Review of the Impact of Parasitic Copepods on Marine Aquaculture. Zool Stud 2004; 43(2): 229-243.

Knoff M, Luque JL, Takemoto RM. Parasitic copepods on Mugil platanus Günther (Osteichthyes: Mugilidae) from the coast of the State of Rio de Janeiro, Brazil. Rev Bras Parasitol Vet 1994; 3(1): 45-56.

Lin CL, Ho JS. Two new species of ergasilid copepods parasitic on fishes cultured in brackish water in Taiwan. Proc Biol Soc Washington 1998; 111(1): 15-27.

Luque JL. Biologia, epidemiologia e controle de parasitos de peixes. Rev Bras Parasitol Vet 2004; 13(S1): 161-165.

Luque JL, Cezar AD. Metazoários ectoparasitos do pampo-galhudo, Trachinotus goodei Jordan \& Evermann, 1896 (Osteichthyes: Carangidae), do litoral do Estado do Rio de Janeiro, Brasil. Acta Sci Biol Sci 2004; 26(1): 19-24. http://dx.doi.org/10.4025/actascibiolsci. v26i1.1654

Luque JL, Chaves ND, Cezar AD. Novos registros de copépodes caligóideos parasitos de peixes marinhos do Brasil. Nauplius 1998; 6(1): 9-16.

McLean E, Salze G, Craig SR. Parasites, diseases and deformities of cobia. Ribarstvo 2008; 66(1): 1-16.
Overstreet RM, Jovonovich J, Ma H. Parasitic crustaceans as vectors of viruses, with an emphasis on three penaeid viruses. Integr Comp Biol 2009; 49(2): 127-141. PMid:21669853. http://dx.doi.org/10.1093/ icb/icp033

Pavanelli GC, Eiras JC, Takemoto RM. Doenças de peixes: profilaxia, diagnóstico e tratamento. 3. ed. Maringá: Eduem; 2008.

Pavanelli GC, Eiras JC, Takemoto RM. Sanidade de Peixes. Inf Agrop 2000; 21(203): 48-52.

Shaffer RV, Nakamura EL. Synopsis of biological data on the cobia Rachycentron canadum (Pisces: Rachycentridae). Washington: U.S. Department of Commerce; 1989.

Schwarz MH, Mowry D, McLean E, Craig SR. Performance of advanced juvenile cobia, Rachycentron canadum, reared under different thermal regimes: evidence for compensatory growth and a method for cold banking. J Appl Aquacult 2007; 19(4): 71-84. http://dx.doi.org/10.1300/ J028v19n04_04

Takemoto RM, Luque JL. Parasitic copepods on Oligoplites spp. (Osteichthyes, Carangidae) from the Brazilian coastal zone, with the redescription of Tuxophorus caligodes Wilson, 1908 (Siphonostomatoida, Tuxophoridae). Acta Sci 2002; 24(2): 481-487.

Varela MC. Parasitas e Parasitoses em Piscicultura. Lisboa: Ordem dos Médicos Veterinários; 2005.

Wilson CB. North American parasitic copepods: New genera and species of Caliginae. Proc US Nat Mus 1908; 33(1580): 593-627.

Woo PTK. Immunological and Therapeutic Strategies against Salmonid Cryptobiosis. J Biomed Biotechnol 2010; 1-9. PMid:20052385 PMCid:2801003. http://dx.doi.org/10.1155/2010/341783

Yamaguti S. Parasitic Copepoda and Branchiura of Fishes. New York: Interscience Publishers; 1963. PMid:14047863. 